\title{
Sleep quality mediates the relationship between risk of obstructive sleep apnea and acute stress in young adults
}

Author name: Kunal Aggarwal ${ }^{1}$

Author name: Nasreen Akhtar²

Author name: Hrudananda Mallick ${ }^{3}$

${ }^{1}$ Author affiliations: MBBS student, All India institute of medical Sciences, New Delhi-110029, India

${ }^{2}$ Author affiliations: Associate Professor, Department of Physiology, All India institute of medical Sciences, New Delhi-110029, India

${ }^{3}$ Author affiliations: Professor, Department of Physiology, SGT University, Gurgaon, Haryana122505, India

Contact details: Email: drnasreenakhtar@gmail.com

${ }^{*}$ Correspondence: Nasreen Akhtar, Room no. 2024, Department of Physiology, AllMS, New

Delhi-110029, India

Tel +911126594053

Email : drnasreenakhtar@gmail.com 


\section{Abstract:}

1 Purpose:

2 Intermittent hypoxia and transient arousals in obstructive sleep apnea (OSA) can lead to poor

3 sleep quality and acute stress. Rising levels of obesity and increased incidence of OSA in young

4 adults predisposes them to acute stress. We propose a mediation model to assess if risk of OSA

5 is associated with acute stress and if the relationship between risk for OSA and acute stress is

6 mediated by sleep quality.

7 Methods:

8493 healthy individuals $(F=237, M=256)$ from $18-25$ years of age (mean age $=20.3 \pm 1.53$ years)

9 were screened for OSA, sleep quality and acute stress using STOP-BANG questionnaire,

10 Pittsburg Sleep Quality Index and American Psychiatry Association's National Stressful Events

11 Survey Acute Stress Disorder Short Scale (NSESS-S) respectively. Binary and logistic regression

12 were used establish the relationships between the variables. Sobel test for mediation analysis

13 was conducted.

\section{Results:}

1573 participants (17.3\%) were found at an intermediate and high risk of OSA by STOP BANG

16 questionnaire. 79 (16\%) participants reported level of stress as 'None'. Mild, moderate and

17 severe stress was present in 248 (50.3\%), 109 (22.1\%), 51 (10.3\%) and 16 (3.2\%) participants

18 respectively. The odds of having severe and extreme stress among those at risk of sleep apnea

19 is 2.18 times higher than that among those not at risk of sleep apnea (OR: $2.18,95 \%$ Confidence

20 Interval: 1.37-3.51). Sobel test established that the relationship between OSA and acute stress is

21 mediated by sleep quality.

\section{Conclusion}

23 Sleep quality mediates the relationship between risk for sleep apnea and acute stress. This

24 highlights the importance of screening for OSA in young adults, particularly young men with high

25 BMI, presenting with high stress levels.

26 Keywords: Emotional stress, sleep apnea, sleep quality, logistic regression, mediation analysis 
medRxiv preprint doi: https://doi.org/10.1101/2021.03.11.21253368; this version posted March 15, 2021. The copyright holder for this preprint (which was not certified by peer review) is the author/funder, who has granted medRxiv a license to display the preprint in perpetuity.

All rights reserved. No reuse allowed without permission.

\section{Introduction}

28 Obstructive sleep apnea (OSA) is characterized by repeated upper airway obstruction causing

29 oxygen desaturation and frequent arousals from sleep[1]. The prevalence of OSA is increasing

30 worldwide. A study from India reported a prevalence of $13.74 \%$ of OSA in general population[2].

31 The frequent desaturations, electroencephographic microarousals and sleep fragmentation in

32 OSA lead to cardiovascular and neuropsychiatric sequalae [3]. OSA has an effect on intellectual

33 abilities related mainly to verbal ability, attention and learning skills including planning and object

34 categorisation [3]. These represent an organic damage to the central nervous system. The

35 awareness of these intellectual impairments, sleep fragmentation and reduced daytime alertness

36 makes the patients feel restless, anxious or depressed [4,5]. This can manifest emotionally as

37 stress. Frequent arousals also cause an increase in catecholamines and cortisol levels,

38 exacerbating the stress. Emotional stress has been found to be higher in patients of OSA and

39 reduces after treatment [6]. OSA has been linked to quality of life [7], ${ }^{7}$ depression, ${ }^{8}$ and anxiety,

409 but the association with acute stress has been reported by very few studies. ${ }^{6,10}$ Most of the

41 studies on OSA have collected data from moderate to severe sleep apnea in older patients and in

42 clinical settings. Occurrence of OSA in general population, particularly among young adults, has

43 been neglected. Young adults are a vulnerable population for higher emotional stress. The

44 current study was conducted in young adults in general population with the objectives to

45 investigate the association of between risk of OSA and acute stress levels and to assess if the

46 association between risk of OSA and acute stress level is mediated by sleep quality. 


\section{$48 \quad$ Material and methods}

\section{Sample and data Collection}

50 This data is obtained from a study conducted in undergraduate college students from various

51 courses in New Delhi from July to September 2019. ${ }^{11}$ Ethical clearance was obtained from

52 Institutional Ethical Committee of All India Institute of Medical Sciences, New Delhi (No IECPG-

53 343/29.05.2019 dated 03.07.2019). The primary objective of the study was to investigate the

54 association between acute stress and risk for obstructive sleep apnea in young adults.

55 This was a cross-sectional and observational study. There was no control group or blinding of 56 assessors. Participants were approached by advertising in college social media groups and 57 announcements in classrooms. The complete information regarding the study and consent form 58 were provided online. All participants gave informed consent for the study and filled the online 59 questionnaire. The questionnaire collected information about the student's age, gender, height, 60 weight, acute stress, risk for sleep apnea and sleep quality. 503 participants between the ages of $61 \quad 18$ and 25 years consented for the study. Those who were previously diagnosed for or on 62 treatment for sleep disorders, psychiatric disorders or any other chronic disease were excluded.

\section{Measures}

65 Risk of sleep apnea was assessed by using STOP-BANG questionnaire (SBQ). ${ }^{12}$ Even though

66 Berlin questionnaire is the one most used in assessments in the clinic, SBQ is the more accurate

67 tool for assessing risk of OSA in the general population. ${ }^{13}$ There were 8-items in the

68 questionnaire. Each positive item was scored as one. The risk was marked low, intermediate and

69 high for a score of 0-2, 3-4 and 5-8 respectively. Intermediate and high risk categories were

70 clubbed into one category for the purpose of analysis in this study as the number of participants

71 in high risk category were very few and would skew the analysis. 
medRxiv preprint doi: https://doi.org/10.1101/2021.03.11.21253368; this version posted March 15, 2021. The copyright holder for this preprint (which was not certified by peer review) is the author/funder, who has granted medRxiv a license to display the preprint in perpetuity.

All rights reserved. No reuse allowed without permission.

72 Sleep quality was assessed by using Pittsburg Sleep Quality Index. ${ }^{14}$ It is a 9-item questionnaire

73 widely used for assessing sleep quality. A score of less than or equal to five was considered good

74 quality sleep, and a score of more than five was considered as poor-quality sleep. Sleep time was

75 distinguished from other activities after going to bed like listening to music or reading books.

76 Acute stress was assessed by American Psychiatry Association Severity of Acute Stress

77 Symptoms—Adult (National Stressful Events Survey Acute Stress Disorder Short Scale

78 [NSESSS]) questionnaire. ${ }^{15}$ It was a 7-item questionnaire. Each item on the measure was rated

79 by the subject on a 5 -point scale $(0=$ Not at all; $1=A$ little bit; $2=$ Moderately; $3=$ quite a bit, and

$804=$ =xtremely). The total raw score ranged from 0 to 28 and a higher score indicated a higher

81 degree of acute stress. This score was divided by 7 (the number of items) to provide a total

82 average score which was allocated a 5-point scale. It was used to assess severity of acute stress

83 as none (0), mild (1), moderate (2), severe (3) and extreme (4). ${ }^{15}$

\section{Analysis}

85 Acute stress, sleep quality and risk for obstructive sleep apnea were correlated to each other

86 using Pearson's bivariate correlation analysis. The Statistical Package for the Social Sciences

87 (SPSS $\left.{ }^{\circledR}\right)$ software version 25.0 (IBM, Armonk NY, USA) for Windows ${ }^{\circledR}$ was used for the

88 correlation analyses. To investigate if risk for sleep apnea is associated with acute stress and if

89 sleep quality mediates the relationship between sleep apnea and acute stress, we created a

90 mediation model (Figure 1). A simple mediation analysis was performed based on the method

91 described by Baron and Kenny. ${ }^{16}$ The dependent (outcome) variable for analysis was acute

92 stress. The independent variable was risk for obstructive sleep apnea. Mediator variable was

93 sleep quality. In our model, we assume there are two causal paths to the dependent variable

94 (acute stress), the direct impact of risk of OSA (path c) and the impact of sleep quality as the

95 mediator (path $a$ and $b$ ). The mediated path from independent variable (Risk of OSA) to the

96 dependant variable (acute stress) is path c'. Binary and ordinal logistic regression were

97 performed using R software (R Core Team 2014 v3.4.4). Mediation analysis was performed using

98 Sobel test. ${ }^{17}$ Sobel test is an accepted test of indirect effect and mediation. ${ }^{18}$ 
medRxiv preprint doi: https://doi.org/10.1101/2021.03.11.21253368; this version posted March 15, 2021. The copyright holder for this preprint (which was not certified by peer review) is the author/funder, who has granted medRxiv a license to display the preprint in perpetuity.

All rights reserved. No reuse allowed without permission.

\section{Results}

100503 volunteers filled up the questionnaire. After applying inclusion and exclusion criteria, 493

101 were included for data analysis. Female: male ratio was $0.91($ Females $=237$, Males $=256$.

102 Mean age of participants was $20.3 \pm 1.53$ years, ranging from 18 to 25 years. The basic

103 descriptives of the study participants are depicted in Table 1.73 participants (17.3\%) were found

104 at an intermediate and high risk of OSA. 79 (16\%) participants reported level of stress as 'None'.

105 The prevalence of mild, moderate and severe stress was 248 (50.3\%), 109 (22.1\%), 51 (10.3\%)

106 and $16(3.2 \%)$ respectively. Mild stress was found higher in males (males- $27.2 \%$, females-

107 23.1\%), whereas moderate, severe and extreme stress was higher in females (Table 1).

108

109 Correlation analysis: Acute stress was significantly correlated with sleep quality $(r=0.328$,

$110 \mathrm{p}<0.001)$, and risk for OSA $(r=0.160, p<0.001)$ (Table 2$)$. Sleep quality also correlates with risk of

111 OSA $(r=0.150, p<0.001)$.

112

113 Logistic Regression and mediation analysis: The assumptions of regression were checked

114 and found satisfactory. First, using steps described by Baron and Kenny, ${ }^{16}$ using acute stress as

115 the dependant variable and risk for obstructive apnea as the independent variable, ordinal logistic

116 regression was applied and risk for obstructive apnea was shown to be a significant predictor

$117(p<0.001)$ of acute stress for all levels of stress (none, mild, moderate, severe and extreme) (c

118 pathway). The odds of having severe and extreme stress among those among those at risk of

119 sleep apnea is 2.18 times higher than that among those not at risk of sleep apnea (OR: 2.18 ,

120 95\% Confidence Interval: 1.37-3.51). Second, risk for sleep apnea was used to predict the

121 mediator variable of sleep quality (a pathway) using binary logistic regression. The odds ratio of

122 poor sleep quality was 2.3 times in a person at high risk of OSA compared to a participant at low

123 risk of OSA (OR: 2.3, 95\% Confidence interval: 1.40-3.83). Third, the relationship between the

124 mediator sleep quality and acute stress was established using ordinal logistic regression (b

125 pathway). On change in sleep quality from good to poor, the odds of mild stress vs moderate or 
medRxiv preprint doi: https://doi.org/10.1101/2021.03.11.21253368; this version posted March 15, 2021. The copyright holder for this preprint (which was not certified by peer review) is the author/funder, who has granted medRxiv a license to display the preprint in perpetuity.

All rights reserved. No reuse allowed without permission.

severe combined are 3.5 times greater (OR: 3.55, 95\% Confidence interval: 2.48-5.11). Last, the mediated relationship between SBQ and acute stress was examined for a reduction in prediction when the mediator was added to the model (c' pathway). Based on a previous study, ${ }^{19}$ the three regression equations were used to test the mediation effects of SQ on relation between OSA and acute stress. Utilizing the coefficients of pathways 'a' and 'b', and Standard Errors ( $\left.\mathrm{S}_{a}, \mathrm{~S}_{\mathrm{b}}\right)$ of these coefficients, mediation was found (Test statistic: 0.7255 ; $p$-value 0.049 , using Sobel test), $[8]^{7}$ showing that the relationship between SB and acute stress was no longer significant after controlling for sleep quality. The Sobel test was used to determine that the 'ab' effect was significantly greater than zero. This provides evidence that the relationship between OSA and acute stress is mediated by sleep quality.

\section{Discussion}

Recurring upper-airway obstruction, intermittent hypoxemia and transient arousals leading to sleep fragmentation and poor sleep quality, are the hall marks of OSA. The risk factors for OSA are male sex, obesity, and advancing age, among others. ${ }^{6}$

Rate of weight gain is greatest in young adults, averaging 1 to 2 pounds per year. ${ }^{20}$ Up to $19 \%$ of teenagers and young adults are reportedly obese in India. ${ }^{21}$ Rising levels of obesity are increasing the prevalence of OSA in young adults. The role of OSA in development of stress in young adults has not been studies much. When presenting with acute stress, young adults are seldom screened for OSA. In this study, our aim is to highlight the importance of screening for OSA in young adults, particularly young men with high BMI, presenting with high stress levels. SBQ has been recommended as the screening tool for OSA in community settings and where PSG is not available. ${ }^{13}$ It is more accurate than Berlin and STOP questionnaire for screening of OSA in general population. ${ }^{13,22} \mathrm{SBQ}$ has a reported sensitivity of is 88,90 and $93 \%$, specificity of 42,36 and $35 \%$, and a diagnostic odds ratio of $5.13,5.05$ and 6.51 for mild, moderate and severe OSA, respectively. ${ }^{13}$ We found a prevalence of intermediate and high risk of sleep apnea to be $14.8 \%$ in our study. It is similar to the prevalence rate of $13.7 \%$ reported by a previous study conducted in Delhi. ${ }^{2}$ We have found a significant association of risk of OSA with acute stress. We 
medRxiv preprint doi: https://doi.org/10.1101/2021.03.11.21253368; this version posted March 15, 2021. The copyright holder for this preprint (which was not certified by peer review) is the author/funder, who has granted medRxiv a license to display the preprint in perpetuity.

All rights reserved. No reuse allowed without permission.

153 presented the result in World Sleep Congress 2019. ${ }^{23}$ The risk of being under severe acute

154 stress was 2.18 times higher in those at risk of OSA than those without the risk of OSA. Other

155 studies have evaluated the association of OSA with emotional stress. Das Santos et al have

156 reported a higher stress level in moderate and severe apnea patients, which reduced significantly

157 after receiving medical or surgical treatment. ${ }^{6}$ Frequent arousals during the night in OSA alter the

158 activity of hypothalamic-pituitary-adrenal axis. Repeated and reversible airway obstruction lead to

159 intermittent hypoxia, sleep fragmentation and decreased sleep duration, causing cortisol and

160 catecholamine release. ${ }^{24-27}$ Cortisol release is associated with higher levels of stress. ${ }^{28}$ This

161 may be contributing to acute stress development in patients of OSA.

162 Second, we assessed if risk for OSA predicts the quality of sleep. As expected, we found higher

163 odds of poor-quality sleep in those at high risk of OSA as compared to those at low risk of OSA.

164 Poor quality of sleep is one the major symptoms of OSA and causes excessive daytime

165 sleepiness and fatigue. ${ }^{1}$ Quality of sleep is closely related to number and extent of arousals.

166 Frequent arousals are a hallmark of OSA. 1,9

167 Third, we assessed if sleep quality can predict acute stress. Using ordinal logistic regression, we

168 found that poor sleep quality leads to 3.5 times higher chance of having moderate/ severe acute

169 stress. Some other studies have found that increased perceived stress and sleep quality are

170 associated with each other. ${ }^{29,30}$ Doane and Thurston found that lower sleep efficiency predicted

171 higher next day stress in adolescents. ${ }^{31} \mathrm{~A}$ few studies have examined the directionality of the

172 relation between stress and sleep and found it to be bidirectional. ${ }^{27,31}$ Sleep quality affects the

173 quality of replenishment of cognitive processes and energy level. ${ }^{32}$ Experimentally produced

174 sleep restriction or sleep loss produces performance decline the next day. ${ }^{32,33}$ Our study is

175 unable to comment on causality or directionality of effect due to a cross-sectional design. The

176 importance of our study lies in relating the sleep quality in everyday settings of the participants to

177 acute stress.

178 Mediation analysis proves our hypothesis that poor sleep quality mediates the relationship

179 between OSA and acute emotional stress. Repeated inspiratory airway occlusion in OSA leads to

180 multiple stressors. The stressors may be frequent episodes of hypoxemia of varying duration and 
medRxiv preprint doi: https://doi.org/10.1101/2021.03.11.21253368; this version posted March 15, 2021. The copyright holder for this preprint (which was not certified by peer review) is the author/funder, who has granted medRxiv a license to display the preprint in perpetuity.

All rights reserved. No reuse allowed without permission.

181

182

183

severity, disrupted sleep due to frequent arousals, reduced total sleep time, and strenuous respiratory efforts resulting in the generation of severe negative intrathoracic pressures. ${ }^{35}$ The neuro-hormonal, vascular and endocrine responses to OSA include excessive sympathetic activation which may carry over to the daytime awake state. ${ }^{36}$ The powerful sympathetic excitatory effects may cause increased glucocorticoids and catecholamines and translate into acute stress. ${ }^{37}$

One of the limitations of our study is the inability to establish the diagnosis of OSA with polysomnography. Further studies using polysomnography for diagnosis of OSA with objective measures of stress such as cortisol levels are required to confirm the findings. Secondly, the duration and onset of acute stress and OSA cannot be determined due to cross sectional design, and hence the temporal association of acute stress with OSA cannot be established.

Based on the findings of our study, we recommend screening for OSA in young adults presenting with acute stress, particularly in overweight males. Further studies using polysomnography for confirmatory diagnosis of OSA and a longitudinal design are recommended to establish causality.

\section{Conclusion}

Increased risk to obstructive sleep apnea among young adults is associated with acute stress, and the relationship is mediated by sleep quality.

\section{Acknowledgments}

We would like to acknowledge the Indian Council of Medical Research. This study was conducted under the Short-Term Studentship Award (STS-2019) conferred by the Indian Council of Medical Research.

\section{Disclosure}

The authors report no conflicts of interest in this work. 
medRxiv preprint doi: https://doi.org/10.1101/2021.03.11.21253368; this version posted March 15, 2021. The copyright holder for this preprint (which was not certified by peer review) is the author/funder, who has granted medRxiv a license to display the preprint in perpetuity.

All rights reserved. No reuse allowed without permission.

205

206

207

208

209

The abstract of this paper was presented at the $15^{\text {th }}$ World Sleep Congress 2019, September 2125, at Vancouver, Canada as a poster presentation with interim findings. The poster's abstract was published in "Poster Abstracts" in the journal 'Sleep medicine' and is available at https://www.sciencedirect.com/journal/sleep-medicine/vol/64/suppl/S1.

\section{References}

1. Sleep-related breathing disorders in adults: recommendations for syndrome definition and measurement techniques in clinical research. The Report of an American Academy of Sleep Medicine Task Force. Sleep. 1999;22(5):667-689.

2. Sharma SK, Kumpawat S, Banga A, Goel A. Prevalence and risk factors of obstructive sleep apnea syndrome in a population of Delhi, India. Chest. 2006;130(1):149-156.

3. Al-Barrak M, Shepertycky MR, Kryger MH. Morbidity and mortality in obstructive sleep apnea syndrome 2: Effect of treatment on neuropsychiatric morbidity and quality of life. Sleep Biol Rhythms. 2003;1(2):65-74.

4. Millman RP, Fogel BS, McNamara ME, Carlisle CC. Depression as a manifestation of obstructive sleep apnea: reversal with nasal continuous positive airway pressure. J Clin Psychiatry. 1989;50(9):348-351.

5. Sforza E, Roche F. Sleep Apnea Syndrome and Cognition. Front Neurol. 2012;3:87.

6. Santos MAG dos, Nakano T de C, Mendes FA, Duarte BB, Marone SAM. Emotional Stress Evaluation of Patients with Moderate and Severe Sleep Apnea Syndrome. Int Arch Otorhinolaryngol. 2017;21(1):28-32.

7. Baldwin CM, Griffith KA, Nieto FJ, O'Connor GT, Walsleben JA, Redline S. The association of sleep-disordered breathing and sleep symptoms with quality of life in the Sleep Heart Health Study. Sleep. 2001;24(1):96-105.

8. Reynolds CF 3rd, Kupfer DJ, McEachran AB, Taska LS, Sewitch DE, Coble PA. Depressive psychopathology in male sleep apneics. J Clin Psychiatry. 1984 Jul;45(7):28790.

9. Macey PM, Woo MA, Kumar R, Cross RL, Harper RM. Relationship between Obstructive 
medRxiv preprint doi: https://doi.org/10.1101/2021.03.11.21253368; this version posted March 15, 2021. The copyright holder for this preprint (which was not certified by peer review) is the author/funder, who has granted medRxiv a license to display the preprint in perpetuity.

All rights reserved. No reuse allowed without permission. Patients. PLOS ONE. 2010;5(4).

10. Chiang JJ, Bower JE, Irwin MR, Taylor SE, Fuligni AJ. Adiposity moderates links from early adversity and depressive symptoms to inflammatory reactivity to acute stress during late adolescence. Brain Behav Immun. 2017;66:146-155.

11. Aggarwal K, Akhtar N, Mallick H. Social jet lag, screen time, physical activity and sleep quality in Indian young adults. Sleep Med. 2019;64:S3-S4.

12. Chung F, Subramanyam R, Liao P, Sasaki E, Shapiro C, Sun Y. High STOP-Bang score indicates a high probability of obstructive sleep apnoea. BJA Br J Anaesth. 2012;108(5):768-775.

13. Chiu H-Y, Chen P-Y, Chuang L-P, et al. Diagnostic accuracy of the Berlin questionnaire, STOP-BANG, STOP, and Epworth sleepiness scale in detecting obstructive sleep apnea:

15. Kilpatrick, D. G., Resnick, H. S., \& Friedman, M. J. (2013a). Severity of Acute Stress [NSESSS]) [Measurement instrument].

16. Baron RM, Kenny DA. The moderator-mediator variable distinction in social psychological research: Conceptual, strategic, and statistical considerations. J Pers Soc Psychol. 1986;51(6):1173-1182.

17. Preacher KJ and Leonardelli GJ. "Calculation for the Sobel Test: An Interactive Calculation Tool for Mediation Tests [Online software]," 2010. Available at: http://quantpsy.org/sobel/sobel.htm. Accessed on October 12, 2020.

18. Preacher KJ and Hayes AF. SPSS and SAS Procedures for Estimating Indirect Effects in Simple Mediation Models. Behaviour Research Methods, Instruments, \& Computers. 2004 (36):717-731. 
medRxiv preprint doi: https://doi.org/10.1101/2021.03.11.21253368; this version posted March 15, 2021. The copyright holder for this preprint (which was not certified by peer review) is the author/funder, who has granted medRxiv a license to display the preprint in perpetuity.

All rights reserved. No reuse allowed without permission.

19. Gangwisch JE, Malaspina D, Posner K, et al. Insomnia and Sleep Duration as Mediators of the Relationship Between Depression and Hypertension Incidence. Am J Hypertens. 2010;23(1):62-69.

20. Wing RR, Tate $\mathrm{D}$, Espeland $\mathrm{M}$, et al. Weight gain prevention in young adults: design of the study of novel approaches to weight gain prevention (SNAP) randomized controlled trial. BMC Public Health. 2013;13(1):300.

21. Jayawardena R, Ranasinghe P, Wijayabandara M, Hills AP, Misra A. Nutrition Transition and Obesity Among Teenagers and Young Adults in South Asia. Curr Diabetes Rev. 2017;13(5):444-451.

22. Nagappa M, Liao P, Wong J, et al. Validation of the STOP-Bang Questionnaire as a Screening Tool for Obstructive Sleep Apnea among Different Populations: A Systematic Review and Meta-Analysis. PloS One. 2015;10(12):e0143697.

23. Aggarwal K, Akhtar N, Mallick HN. High risk of sleep apnoea is associated with acute stress in young adults. Sleep Med. 2019;64:S7.

24. Miller JN, Berger AM. Screening and assessment for obstructive sleep apnea in primary care. Sleep Med Rev. 2016;29:41-51.

25. Bradley TD, Floras JS. Obstructive sleep apnoea and its cardiovascular consequences. Lancet Lond Engl. 2009;373(9657):82-93.

26. Young T, Finn L, Peppard PE, et al. Sleep Disordered Breathing and Mortality: EighteenYear Follow-up of the Wisconsin Sleep Cohort. Sleep. 2008;31(8):1071-1078.

27. Buckley TM, Schatzberg AF. On the interactions of the hypothalamic-pituitary-adrenal (HPA) axis and sleep: normal HPA axis activity and circadian rhythm, exemplary sleep disorders. J Clin Endocrinol Metab. 2005;90(5):3106-3114.

28. McEwen BS. Central effects of stress hormones in health and disease: understanding the protective and damaging effects of stress and stress mediators. Eur J Pharmacol. 2008;583(2-3):174-185.

29. Doolin J, Vilches JE, Cooper C, Gipson C, Sorensen W. Perceived stress and worldview influence sleep quality in Bolivian and United States university students. Sleep Health. 
medRxiv preprint doi: https://doi.org/10.1101/2021.03.11.21253368; this version posted March 15, 2021. The copyright holder for this preprint

(which was not certified by peer review) is the author/funder, who has granted medRxiv a license to display the preprint in perpetuity.

All rights reserved. No reuse allowed without permission.

2018;4(6):565-571.

30. Roskoden FC, Krüger J, Vogt LJ, et al. Physical Activity, Energy Expenditure, Nutritional Habits, Quality of Sleep and Stress Levels in Shift-Working Health Care Personnel. PloS One. 2017;12(1):e0169983.

31. Doane LD, Thurston EC. Associations among sleep, daily experiences, and loneliness in adolescence: Evidence of moderating and bidirectional pathways. $J$ Adolesc. $2014 ; 37(2): 145-154$.

32. Yap Y, Slavish DC, Taylor DJ, Bei B, Wiley JF. Bi-directional relations between stress and self-reported and actigraphy-assessed sleep: a daily intensive longitudinal study. Sleep. 2020;43(3).

33. Pejovic S, Basta M, Vgontzas AN, et al. Effects of recovery sleep after one work week of mild sleep restriction on interleukin- 6 and cortisol secretion and daytime sleepiness and performance. Am J Physiol - Endocrinol Metab. 2013;305(7):E890-E896.

34. Vgontzas AN, Tsigos C, Bixler EO, Stratakis CA, Zachman K, Kales A, Vela-Bueno A, Chrousos GP. Chronic insomnia and activity of the stress system: a preliminary study. J Psychosom Res. 1998 Jul;45(1):21-31.

35. Lopez-Jimenez F, Somers VK. Stress measures linking sleep apnea, hypertension and diabetes--AHI vs arousals vs hypoxemia. Sleep. 2006;29(6):743-744.

36. Somers VK, Dyken ME, Clary MP, Abboud FM. Sympathetic neural mechanisms in obstructive sleep apnea. J Clin Invest. 1995;96(4):1897-1904. cytokines, and autoimmunity. Ann N Y Acad Sci. 2002;966:290-303. 
medRxiv preprint doi: https://doi.org/10.1101/2021.03.11.21253368; this version posted March 15, 2021. The copyright holder for this preprint (which was not certified by peer review) is the author/funder, who has granted medRxiv a license to display the preprint in perpetuity. All rights reserved. No reuse allowed without permission.

311 Table 1 Basic descriptives of the study participants

312

\begin{tabular}{|c|c|c|c|c|}
\hline S.No & Characteristic & $\begin{array}{l}\text { Total } \\
(n=493)\end{array}$ & $\begin{array}{l}\text { Male } \\
(\mathrm{n}=256)\end{array}$ & $\begin{array}{l}\text { Female } \\
(\mathrm{n}=237)\end{array}$ \\
\hline 1 & Age (years) Mean \pm SD & $20.3 \pm 1.53$ & $20.04 \pm 1.46$ & $20.59 \pm 1.57$ \\
\hline 2 & BMI $\left(\mathrm{Kg} / \mathrm{m}^{2}\right)$ Mean $\pm \mathrm{SD}$ & $22.7 \pm 3.77$ & $22.97 \pm 3.49$ & $20.44 \pm 3.91$ \\
\hline \multicolumn{5}{|c|}{3 Acute stress } \\
\hline & None (0) & $69(14 \%)$ & $43(8.7 \%)$ & $26(5.3 \%)$ \\
\hline & Mild (1) & $248(50.3 \%)$ & $134(27.2 \%)$ & $114(23.1 \%)$ \\
\hline & Moderate(2) & $109(22.1 \%)$ & $49(9.9 \%)$ & $60(12.2 \%)$ \\
\hline & Severe (3) & $51(10.3 \%)$ & $25(5.1 \%)$ & $26(5.3 \%)$ \\
\hline & Extreme (4) & $16(3.2 \%)$ & $5(1.0 \%)$ & $11(2.2 \%)$ \\
\hline \multicolumn{5}{|c|}{5 Risk of Obstructive Sleep Apnea } \\
\hline & Low risk & $420(85.2 \%)$ & $192(75 \%)$ & $228(96.2 \%)$ \\
\hline & Intermediate + High risk & $73(14.8 \%)$ & $64(25 \%)$ & $9(3.7 \%)$ \\
\hline \multicolumn{5}{|c|}{6 Sleep quality (PSQI) } \\
\hline & Good (Score 1-5) & $315(63.9 \%)$ & $173(35.1 \%)$ & $142(28.8 \%)$ \\
\hline & Poor (Score 5- 21) & $178(36.1 \%)$ & $83(16.8 \%)$ & 95 (19.3\%) \\
\hline
\end{tabular}

313

\section{Notes:}

315 Abbreviations: SD, Standard Deviation, PSQI, Pittsburg Sleep Quality Index 
medRxiv preprint doi: https://doi.org/10.1101/2021.03.11.21253368; this version posted March 15, 2021. The copyright holder for this preprint (which was not certified by peer review) is the author/funder, who has granted medRxiv a license to display the preprint in perpetuity. All rights reserved. No reuse allowed without permission.

317 Table 2: Correlation between acute stress, Sleep Quality and Risk of OSA

\begin{tabular}{|l|l|l|l|}
\hline & Acute stress & Sleep quality & Risk of OSA \\
\hline Acute stress & 1 & $.328^{\star *}$ & $.160^{\star *}$ \\
\hline PSQI & & 1 & $.150^{\star *}$ \\
\hline SB & & & 1 \\
\hline
\end{tabular}

319 Abbreviations: OSA, Obstructive Sleep Apnea

$320 \quad$ Figure 1 Mediation model

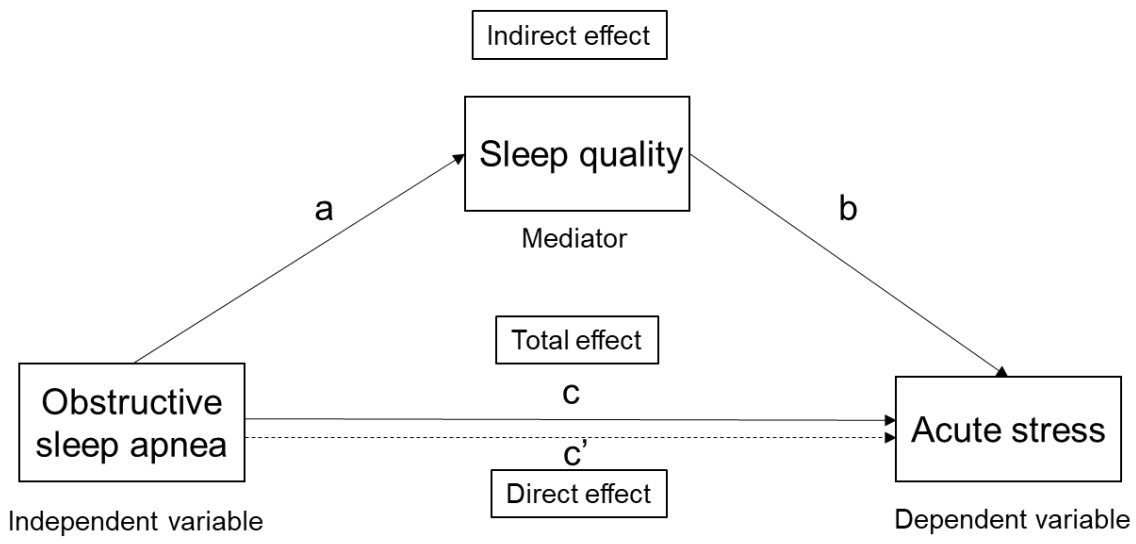

Figure 2 Mediation model with effect size.

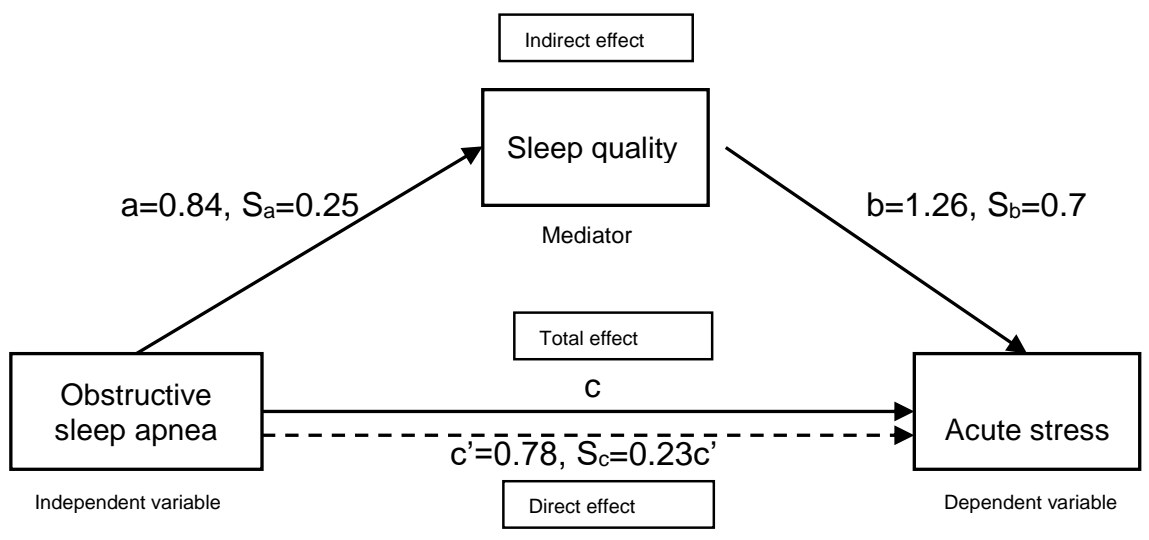

Legend: a, Regression coefficient of pathway 'a'; b, Regression coefficient of pathway ' $b$ '; c, Regression 